\title{
Culicoides Biting Midges-Underestimated Vectors for Arboviruses of Public Health and Veterinary Importance
}

\author{
Franziska Sick ${ }^{1}$, Martin Beer ${ }^{1}$, Helge Kampen ${ }^{2}$ and Kerstin Wernike ${ }^{1, * \mathbb{C}}$ \\ 1 Institute of Diagnostic Virology, Friedrich-Loeffler-Institut, Suedufer 10, 17493 Greifswald-Insel Riems, \\ Germany; Franziska.Sick@fli.de (F.S.); Martin.Beer@fli.de (M.B.) \\ 2 Institute of Infectology, Friedrich-Loeffler-Institut, Suedufer 10, 17493 Greifswald-Insel Riems, Germany; \\ Helge.Kampen@fli.de \\ * Correspondence: Kerstin.Wernike@fli.de; Tel.: +49-38351-71212
}

Received: 26 March 2019; Accepted: 18 April 2019; Published: 24 April 2019

\begin{abstract}
Culicoides biting midges, small hematophagous dipterans, are the demonstrated or putative vectors of multiple arboviruses of veterinary and public health importance. Despite its relevance in disease spread, the ceratopogonid genus Culicoides is still a largely neglected group of species, predominantly because the major human-affecting arboviruses are considered to be transmitted by mosquitoes. However, when a pathogen is detected in a certain vector species, a thorough search for further vectors often remains undone and, therefore, the relevant vector species may remain unknown. Furthermore, for many hematophagous arthropods, true vector competence is often merely suspected and not experimentally proven. Therefore, we aim to illuminate the general impact of Culicoides biting midges and to summarize the knowledge about biting midge-borne disease agents using the order Bunyavirales, the largest and most diverse group of RNA viruses, as an example. When considering only viruses evidentially transmitted by Culicoides midges, the Simbu serogroup (genus Orthobunyavirus) is presumably the most important group within the virus order. Its members are of great veterinary importance, as a variety of simbuviruses, e.g., the species Akabane orthobunyavirus or Schmallenberg orthobunyavirus, induces severe congenital infections in pregnant animals. The major zoonotic representative of this serogroup occurs in South and Central America and causes the so-called Oropouche fever, an acute febrile illness in humans.
\end{abstract}

Keywords: Culicoides; biting midges; transmission; insect vector; Bunyavirales; orthobunyavirus; Simbu serogroup; Schmallenberg virus; Akabane virus

\section{Introduction}

During the last decade, the incidence of emerging viral diseases has increased considerably in various regions worldwide. Diseases such as Zika fever or West Nile fever have been among numerous neglected viral diseases, until they have expanded to new regions and caused large outbreaks, thereby attracting strong media attention [1,2]. Among the emerging or re-emerging pathogenic viruses are a large number of so-called arthropod-borne (arbo) viruses, i.e., viruses that are transmitted between their vertebrate hosts by insects and other arthropods [3].

For the establishment and maintenance of "virus-vector-host" transmission cycles of arboviruses in a given area, competent vectors and susceptible hosts need to encounter under favorable environmental conditions [4]. Hence, as reasons for the increasing number of reported arbovirus-induced disease outbreaks, factors such as climate change, increasing urbanization, and globalization with increasing trade, livestock movement, and increasing traveling activities are discussed [5]. 
Medically, one of the most highly important arthropod vectors is unquestionably mosquitoes. Nonetheless, further, sometimes neglected arthropods such as ticks or biting midges can also act as vectors of emerging disease agents [6]. However, when a pathogen has been detected in a certain vector species, a thorough search for further putative vectors often remains undone. Furthermore, the mere demonstration of a pathogen in a blood-feeding arthropod is often mistaken as evidence for vector competence of that arthropod species without further experimental studies. Therefore, we want to summarize here knowledge about ceratopogonid-transmitted disease agents and their impact on human and animal health focusing on Culicoides biting midges and the new viral order Bunyavirales, which contains the largest and most diverse families of RNA viruses [7]. In this review, we illuminate the general impact of Culicoides biting midges, an often-neglected insect vector, but primarily, we present evidence of their role in the transmission of selected orthobunyaviruses of public health or veterinary importance.

\section{How to Differentiate Mechanical from Biological Vectors?}

Vector competence refers to the physiological ability of arthropods to acquire and maintain microbial agents from a host, and later transmit them to the next susceptible host [8]. The mere virus detection in a midge does not necessarily indicate vector competence. A midge feeding on a viremic host can carry virus from the blood meal in its gut without being infected itself. However, it can subsequently serve as a so-called "mechanical vector" for virus transmission. To understand a disease and its epidemiology entirely, it is essential to distinguish biological (competent) from pure mechanical vectors.

One option to examine the vector competence is the separate analysis of the head and the salivary glands and the rest of the insect body. Virus detection in the salivary glands is a sign for a biological infection followed by virus dissemination, resulting in a potential virus transmission via saliva. Hence, virus detection in the salivary glands of an insect hints at true vector competence. On the other hand, detection of virus in the completely homogenized body of the insect may indicate just the ingestion of a viremic blood meal, which not necessarily leads to an infection of the insect.

To evaluate vector competence in more detail, infection studies under laboratory conditions either with biting midges caught in the field or with laboratory-adapted colonies are a suitable method. Insects can be artificially infected by intrathoracic inoculation of virus directly into the hemolymph bypassing the intestinal ("gut") barrier, or orally by feeding viremic blood. Subsequently, after an extrinsic incubation period, samples are collected from surviving individuals. The insects themselves could be examined as a whole or with head plus salivary glands and body separated as described above. Furthermore, saliva could be collected from individual insects and tested for infectious virus or viral genome. From the results, infection, dissemination and transmission rates are calculable [9].

\section{Culicoides Biting Midges: Classification, Morphological Characteristics, and Distribution}

Culicoides is a genus of biting midges in the order Diptera, family Ceratopogonidae. Currently, the genus contains 1368 species divided into numerous subgenera [10].

Culicoides biting midges are among the most abundant hematophagous insects worldwide, occurring from temperate areas to the tropics. Representing one of the smallest hematophagous flies, they measure only 1-3 mm [11]. Their mouthparts form a proboscis well adapted for cutting skin and sucking blood. Wings are well developed, and biting midges are commonly identified to complex or species level based on the wing maculation [12]. However, this method of identification is very time consuming and depends on the professional experience of the examiner. Alternative methods use genome amplification by polymerase chain reaction (PCR) with subsequent sequencing and phylogenetic comparison of DNA marker regions [13,14]. In addition, real-time PCR assays have been established for a few Culicoides species [15,16], a DNA microarray was developed to identify Culicoides species of the obsoletus group [17], and matrix-assisted laser desorption/ionization time-of flight mass spectrometry (MALDI-TOF-MS) has been used to identify Culicoides species based on peptide and protein signatures [18]. 
The life cycle of Culicoides, which passes through the egg stage, four larval stages, a pupa, and the imago, requires a certain amount of free water or moisture, and some species occur in both fresh water and estuarine environments. Breeding sites range from pools, streams, tree holes to saturated soil, animal dung and rotting vegetation [19]. Females depend on blood for the maturation of the eggs; they feed, depending on the species, on mammals and/or birds. Males do not feed on blood, and can survive on nectar alone. The development of Culicoides species takes a few weeks-or even months, when overwintering in a larval stage - and this process depends on the ambient temperatures, resulting in a seasonal activity pattern in temperate regions. In mild climatic zones, the insect numbers start to increase in late spring and early summer and usually peak in late summer or early autumn $[11,20]$. With the onset of low temperatures and the first frosts, the number of active insects drops dramatically.

In general, adult biting midges are short-lived and only a few individuals survive longer than 10 to 20 days. During this time, females may feed on hosts multiple times [11].

\section{Public Health and Veterinary Impact of Culicoides Biting Midges}

Biting midge bites can cause painful lesions; in some cases, the saliva even induces acute allergic reactions such as the "common summer eczema (insect hypersensitivity)" in horses [21]. However, their veterinary or public health importance predominantly results from their role in the transmission of pathogens, especially viruses, but also protozoans and filarial parasites [22] such as avian hamosporidians [23,24] and Tetrapetalonema spp. [25-27]. More than 50 viruses have been isolated from Culicoides spp. worldwide [28,29]. Most of the viruses belong to the families Reoviridae (e.g., African horse sickness virus (AHSV), bluetongue virus (BTV), or epizootic hemorrhagic disease virus (EHDV)), Rhabdoviridae (e.g., bovine ephemeral fever virus (BEFV)) and Peribunyaviridae (e.g., Akabane virus (AKAV), Schmallenberg virus (SBV), or Oropouche virus (OROV)). However, some viruses isolated from Culicoides are only incidental findings, such as Rift Valley fever virus (RVFV), which is mainly transmitted by mosquitoes $[28,30]$. Furthermore, vector competence studies are still missing for a wide range of viruses suspected to be transmitted by Culicoides.

Surveillance on biting midges and biting midge-borne diseases is carried out in various countries of several continents. As an example, the distribution and potential spread of BTV is monitored by the collection of biting midges in virtually every affected European country, also to define e.g., a so-called "seasonally vector free" period. To sample the adult Culicoides population, light-suction traps placed at sentinel sites across outbreak areas are the most commonly used standardized trap system [31]. Furthermore, detailed studies on local dispersal of Culicoides are available from Australia, comparing various types of light traps with different outcomes in biting midge catches [32] and analyzing distribution patterns related to weather and climate [33].

In search for potential vector species, an accurate estimate of species actually biting the vertebrate host is vital. In the context of BTV vector search in Europe, it was demonstrated in a comparative study of light-suction traps and drop catches that the biting midges caught in light-suction traps do not provide an accurate reflection of the biting Culicoides population [31], which has to be considered when assessing data collected in such surveillance studies.

Because of the needs of their agents' vectors, Culicoides-borne diseases are strongly linked to climate and weather. In temperate regions, the seasonal pattern of virus transmission coincides with warm, moist summer and autumn months. In tropical and subtropical regions, high vertebrate infection rates have been reported during wet summer and declining transmission rates in periods of lower rainfall [34]. Although their flight range does not exceed a few hundred meters, biting midges can be dispersed passively over great distances by wind [35-38], further contributing to their impact on disease epidemiology.

The establishment of laboratory colonies poses great difficulties, especially because field-collected specimens fail to mate under laboratory conditions. So far, very few Culicoides species have been successfully reared under laboratory conditions $[29,39,40]$ and, consequently, are available for studies on their vector competence. Most laboratory colonies represent $C$. nubeculosus and C. sonorensis, rendering these two species 
important models for studying arbovirus transmission by Culicoides biting midges [41]. Due to difficulties in acquiring biting midges from the field for laboratory studies caused by the characteristics of the insects, the major part of data available on experimental infections pertain to C. nubeculosus and C. sonorensis.

\section{The Genus Orthobunyavirus}

Only recently, the International Committee on Taxonomy of Viruses (ICTV) made some fundamental changes in the taxonomy of the order Bunyavirales, which had been established in 2017 to accommodate viruses with linear, segmented, single-stranded RNA genome [42]. In early 2019, the order was taxonomically revised by creating several new families, subfamilies, genera, and species. As of February 2019, the order Bunyavirales consists of 46 genera assigned to 12 distinct families [7]. One of the genera belonging to the newly established family Peribunyaviridae is the genus Orthobunyavirus, which contains more than 170 unanimous insect-transmitted viruses in 18 serogroups, of which the Simbu serogroup is not only one of the largest, but also the most important in terms of veterinary public health. For human health, the California encephalitis serogroup is very likely the most relevant one as it contains, e.g., La Crosse virus (LACV).

In general, orthobunyaviruses are spherical, about $100 \mathrm{~nm}$ in diameter and relatively simple in their composition as the tri-partite RNA genome encodes only four structural and two non-structural proteins. The small (S) genomic segment encodes for the nucleocapsid protein $\mathrm{N}$ and the non-structural protein NSs, while the medium (M) segment encodes for the glycoproteins Gn and Gc, which form spikes on the surface of the virus particle, and the non-structural protein NSm. The large (L) segment encodes for the RNA dependent RNA polymerase [43].

The glycoproteins Gn and Gc are integral transmembrane proteins which are important for viral attachment, membrane fusion and the induction of the host's immune response [44-46]. The N-protein is essential for viral RNA transcription and replication, and it forms ribonucleoprotein complexes with the three viral RNA segments. These complexes are associated with the L-protein $[47,48]$. The NSs-protein is a major virulence factor in vertebrate hosts as it acts as an interferon antagonist and is responsible for the shut-off of protein synthesis in mammalian hosts cells [48]. In vertebrate hosts, the NSm-protein is associated with virus assembly and morphogenesis [49]. However, the function of both non-structural proteins, NSs and NSm, in the insect vectors is largely unknown.

\subsection{The Simbu Serogroup}

When considering only viruses evidentially transmitted by Culicoides midges, the Simbu serogroup is presumably the most important group within the genus Orthobunyavirus. Furthermore, its members are of great veterinary importance, as a variety of simbuviruses induces severe congenital infections in pregnant animals. The serogroup currently consists of 32 viruses grouped into 19 virus species (Table 1). Simbuviruses are distributed worldwide (Table 1, Figure 1), and they persist in nature by alternately infecting mammalian hosts and Culicoides vectors. In endemic regions, Simbu serogroup viruses establish a pattern of cyclic circulation, with seasons of high virus appearance followed by periods of only sporadic detection [50-55], which is presumably related to the overall immunity in the host population and the abundance of Culicoides vectors.

Important representatives of the Simbu serogroup are AKAV and SBV, which predominantly infect ruminants. Infections of adults are either asymptomatic or mild, associated with fever, diarrhea, and decrease in milk yield for a few days. Infections of naïve dams during a critical phase of gestation, however, may be followed by abortion, premature birth, mummification, stillbirth or congenital deformations referred to as arthrogryposis-hydranencephaly syndrome [34,56]. Further ruminant-infecting Simbu serogroup viruses that might induce similar clinical signs as AKAV or SBV include Shuni virus (SHUV), Aino virus (AINOV) and the eponymous Simbu virus (SIMV) [57] (Table 1). The only zoonotic virus of this serogroup is OROV (and reassortants such as Iquitos virus and Madre de Dios virus), which is present in South America (Figure 1). 


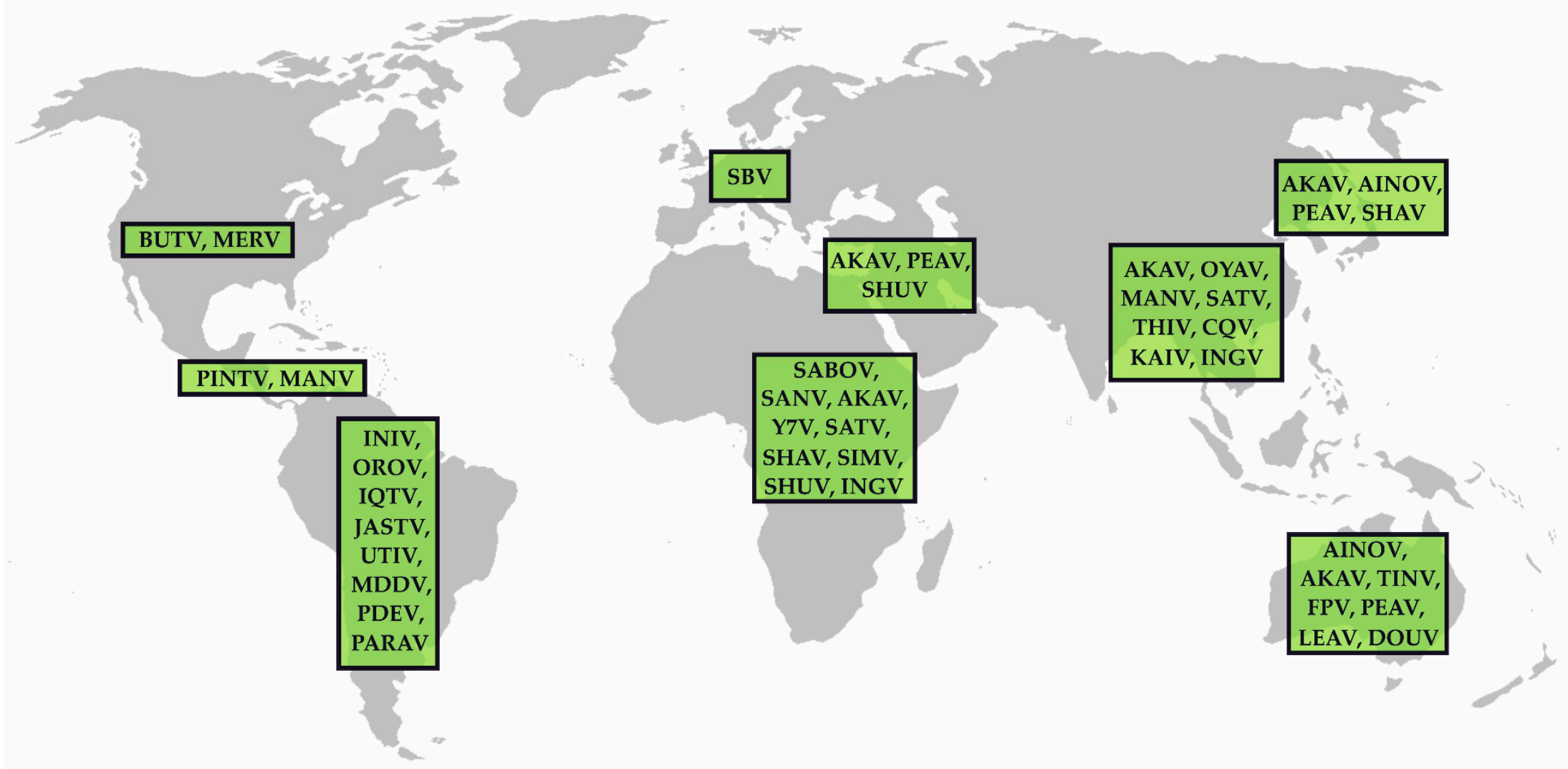

Figure 1. Distribution of Simbu serogroup viruses. The meanings of the abbreviations (virus names) are listed in Table 1. 
Table 1. Classification and distribution of Simbu serogroup viruses and vector species responsible for their transmission.

\begin{tabular}{|c|c|c|c|c|c|c|c|c|c|}
\hline \multirow{2}{*}{ Virus Species } & \multirow{2}{*}{ Virus (Abbreviation) } & \multicolumn{3}{|c|}{ First Isolation } & \multicolumn{2}{|l|}{ Insect Vector } & \multicolumn{2}{|c|}{ Distribution } & \multirow[b]{2}{*}{$\begin{array}{l}\text { Reference (1st } \\
\text { Description) }\end{array}$} \\
\hline & & Year & Country & Organism & Putative Vectors & Demonstrated Vectors & Continent & $\begin{array}{l}\text { Animal Hosts (Virus } \\
\text { Detection) }\end{array}$ & \\
\hline \multirow[t]{2}{*}{ Akabane orthobunyavirus } & Akabane virus (AKAV) & 1959 & Japan & mosquitoes & biting midges, mosquitoes & C. brevitarsis, C. variipennis ${ }^{1}$ & Asia, Africa, & ruminants, swine & [58] \\
\hline & $\begin{array}{l}\text { Tinaroo virus (TINV) } \\
\text { Yaba-7 virus (T7V) }\end{array}$ & $\begin{array}{l}1978 \\
1963\end{array}$ & $\begin{array}{l}\text { Australia } \\
\text { Nigeriaa }\end{array}$ & $\begin{array}{l}\text { Culicoides midges } \\
\text { mosquitoes }\end{array}$ & biting midges (C. brevitarsis) & & $\begin{array}{l}\text { Australia } \\
\text { Africa }\end{array}$ & ruminants & {$[59]$} \\
\hline \multirow{2}{*}{$\begin{array}{l}\text { Aino orthobunyavirus } \\
\text { Buttonwillow } \\
\text { orthobunyavirus }\end{array}$} & Aino virus (AINOV) & 1964 & Japan & mosquitoes & mosquitoes, biting midges (C. brevitarsis) & & Asia, Australia & ruminants & [61] \\
\hline & Buttonwillow virus (BUTV) & 1962 & USA & Cottontail rabbit & midges (C. variipennis) & & North America & leproids & [62] \\
\hline \multirow[t]{2}{*}{ Cat Que orthobunyavirus } & Cát Quế virus (CQV) & 2004 & Vietnam & mosquitoes & $\begin{array}{l}\text { mosquitoes (Culex spp., Anopheles spp., } \\
\text { Mansonia spp.) }\end{array}$ & & Asia & swine, birds & [63] \\
\hline & Oya virus (OYAV) & 1999 & Malaysia & swine & mosquitoes & & Asia & swine, humans & [64] \\
\hline \multirow{4}{*}{$\begin{array}{l}\text { Faceys paddock } \\
\text { orthobunyavirus } \\
\text { Ingwavuma } \\
\text { orthobunyavirus } \\
\text { Jatobal orthobunyavirus } \\
\text { Leanyer orthobunyavirus } \\
\text { Manzanilla } \\
\text { orthobunyavirus }\end{array}$} & $\begin{array}{l}\text { Facey's paddock virus } \\
\text { (FPV) }\end{array}$ & 1974 & Australia & mosquitoes & mosquitoes (Culex annulirostris), midges & & Australia & & [65] \\
\hline & Ingwavuma virus (INGV) & 1959 & South Africa & spectacled weaver & $\begin{array}{l}\text { mosquitoes (Culex spp., Monsonia spp.), } \\
\text { biting midges }\end{array}$ & & Africa, Asia & swine, dogs, birds & [66] \\
\hline & $\begin{array}{l}\text { Jatobal virus (JASTV) } \\
\text { Leanyer virus (LEAV) }\end{array}$ & $\begin{array}{l}1985 \\
1974\end{array}$ & $\begin{array}{l}\text { Brazil } \\
\text { Australia }\end{array}$ & $\begin{array}{c}\text { coati } \\
\text { mosquitoes }\end{array}$ & $\begin{array}{l}\text { mosquitoes, biting midges } \\
\text { mosquitoes (Anopheles meraukensis) }\end{array}$ & & $\begin{array}{l}\text { South America } \\
\text { Australia }\end{array}$ & $\begin{array}{c}\text { coati } \\
\text { cattle, wallabies, dogs }\end{array}$ & {$[67]$} \\
\hline & Manzanilla virus (MANV) & 1954 & Trinidad & Howler monkey & $\begin{array}{l}\text { mosquitoes (Culex tritaeniorhynchus), } \\
\text { biting midges }\end{array}$ & & $\begin{array}{l}\text { Central America, } \\
\text { Asia }\end{array}$ & & {$[69]$} \\
\hline \multirow{6}{*}{$\begin{array}{l}\text { Mermet orthobunyavirus } \\
\text { Oropouche orthobunyavirus }\end{array}$} & $\begin{array}{l}\text { Inini virus (INIV) } \\
\text { Mermet virus (MERV) } \\
\text { Iquitos virus (IOTV) }\end{array}$ & $\begin{array}{l}1973 \\
1964 \\
1999\end{array}$ & $\begin{array}{l}\text { French Guaiana } \\
\text { USA }\end{array}$ & $\begin{array}{l}\text { Aracari bird } \\
\text { purple martin }\end{array}$ & mosquitoes (Culex spp.) & & $\begin{array}{l}\text { South America } \\
\text { North America }\end{array}$ & $\begin{array}{l}\text { birds } \\
\text { birds }\end{array}$ & {$\left[\begin{array}{l}{[70]} \\
{[71]}\end{array}\right.$} \\
\hline & $\begin{array}{l}\text { Iquitos virus (IQTV) } \\
\text { Madre de Dios virus }\end{array}$ & 1999 & Peru & human & midges & & South America & humans & [72] \\
\hline & $\begin{array}{l}\text { Madre de Dios virus } \\
\text { (MDDV) }\end{array}$ & 2007 & Peru & human & mosquitoes, biting midges & & South America & humans, monkeys & [73] \\
\hline & Oropouche virus (OROV) & 1955 & Trinidad & human & $\begin{array}{l}\text { mosquitoes (Aedes spp., Coquillettidia } \\
\text { venezuelensis, Culex quinquefasciatus), } \\
\text { biting midges }\end{array}$ & C. paraensis & $\begin{array}{l}\text { Central/South } \\
\text { America }\end{array}$ & $\begin{array}{l}\text { sloths, non-human } \\
\text { primates, rodents, birds, } \\
\text { humans }\end{array}$ & [74] \\
\hline & Perdões virus (PDEV) & 2012 & Brazil & $\begin{array}{l}\text { black-tufted } \\
\text { marmoset }\end{array}$ & & & South America & non-human primates & [75] \\
\hline & Pintupo virus (PINTV) & & Panama & $\begin{array}{l}\text { marmoset } \\
\text { sloth }\end{array}$ & biting midges & & Central America & sloths & [76] \\
\hline Peaton orthobunyavirus & Peaton virus (PEAV) & 1976 & Australia & Culicoides spp. & biting midges (C. brevitarsis, C. imicola, C. & & Australia, Asia & ruminants, horses & [77] \\
\hline \multirow{4}{*}{$\begin{array}{l}\text { Sabo orthobunyavirus } \\
\text { Sango orthobunyavirus } \\
\text { Schmallenberg } \\
\text { orthobunyavirus }\end{array}$} & $\begin{array}{l}\text { Sabo virus (SABOV) } \\
\text { Sango virus (SANV) }\end{array}$ & $\begin{array}{l}1966 \\
1965\end{array}$ & $\begin{array}{l}\text { Nigeria } \\
\text { Nigeria }\end{array}$ & $\begin{array}{c}\text { goat } \\
\text { cattle }\end{array}$ & $\begin{array}{c}\text { Jacoossonil } \\
\text { biting midges } \\
\text { mosquitoes, biting midges }\end{array}$ & & $\begin{array}{l}\text { Africa } \\
\text { Africa }\end{array}$ & $\begin{array}{l}\text { goat } \\
\text { cattle }\end{array}$ & $\begin{array}{l}{[60]} \\
{[60]}\end{array}$ \\
\hline & Douglas virus (DOUV) & 1978 & Australia & cattle & biting midges (C. brevitarsis) & & Australia/Oceania & ruminants & [59] \\
\hline & Sathuperi virus (SATV) & 1957 & India & mosquitoes & $\begin{array}{l}\text { mosquitoes (Culex vishnui), biting midges } \\
\text { (C. oxystoma) }\end{array}$ & & Asia, Africa & ruminants & [78] \\
\hline & Schmallenberg virus (SBV) & 2011 & Germany & cattle & biting midges & $\begin{array}{l}\text { biting midges (C. obsoletus, } \\
\text { C. scoticus, C. chiopterus, }, . \\
\text { imicola, C. sonorensis }{ }^{1} \text { ). }\end{array}$ & Europe & ruminants & [79] \\
\hline \multirow[t]{2}{*}{ Shuni orthobunyavirus } & $\begin{array}{l}\text { Shamonda virus (SHAV) } \\
\text { Kaikalur virus (KAIV) }\end{array}$ & $\begin{array}{l}1965 \\
1971\end{array}$ & $\begin{array}{l}\text { Nigeria } \\
\text { India }\end{array}$ & $\begin{array}{c}\text { cattle } \\
\text { mosquitoes }\end{array}$ & $\begin{array}{l}\text { biting midges } \\
\text { mosquitoes }\end{array}$ & & $\begin{array}{l}\text { Africa, Asia } \\
\text { Asia }\end{array}$ & ruminants & $\begin{array}{l}{[60]} \\
{[80]}\end{array}$ \\
\hline & Shuni virus (SHUV) & 1966 & Nigeria & cattle & mosquitoes (Culex theileri), biting midges & $\begin{array}{l}\text { biting midges (C. } \\
\text { nubeculosus }{ }^{1}, \text { C. sonorensis } \\
{ }_{1} \text { ). }\end{array}$ & Africa, Asia & $\begin{array}{l}\text { ruminants, horse, } \\
\text { (humans?) }\end{array}$ & [60] \\
\hline Simbu orthobunyavirus & $\begin{array}{l}\text { Para virus (PARAV) } \\
\text { Simbu virus (SIMV) }\end{array}$ & 1955 & $\begin{array}{l}\text { Argentina } \\
\text { South Africa }\end{array}$ & $\begin{array}{l}\text { mosquitoes } \\
\text { mosquitoes }\end{array}$ & $\begin{array}{c}\text { mosquitoes } \\
\text { mosquitoes (Aedes spp.), biting midges }\end{array}$ & & $\begin{array}{l}\text { South America } \\
\text { Africa }\end{array}$ & & $\begin{array}{l}{[81]} \\
{[82]}\end{array}$ \\
\hline Thimiri orthobunyavirus & Thimiri virus (THIV) & 1963 & India & Indian Pond Heron & biting midges (C. histrio) & & Asia & birds & [83] \\
\hline Utinga orthobunyavirus & Utinga virus (UTIV) & 1965 & Brazil & $\begin{array}{l}\text { brown-throated } \\
\text { sloth }\end{array}$ & ? & & South America & sloths & [84] \\
\hline
\end{tabular}

${ }^{1}$ laboratory-adapted species, not naturally found in areas where the respective virus circulates. 


\subsubsection{AKAV}

AKAV was first described in the 1950s in Japan and is now endemic in large parts of Asia, the Middle East, Australia and Africa $[34,57,85,86]$. The virus may induce abnormal courses of pregnancy and fetal malformation in ruminants as described for both AKAV and SBV [34]. In addition, some strains might occasionally cause encephalitis in newborn calves. The Iriki strain, which is present in Japan and Korea, has been in rare cases associated with encephalitis in adult cattle [87-89].

Although AKAV was initially isolated from mosquitoes, they do not seem to play an important epidemiological role in virus transmission [90]. In contrast, depending on geographical regions, various Culicoides species are considered the main vectors and responsible for virus spread.

For Australia, the assumed main vector is C. brevitarsis [91,92], since it was demonstrated that AKAV replicates in C. brevitarsis to high virus titers and reaches the salivary glands after 10 days of incubation [93]. Furthermore, the virus has been isolated from C. wadai in Australia [94]. In Japan, C. oxystoma is considered the major vector [51,95], although AKAV was also isolated from the mosquito species Aedes vexans and Culex tritaeniorhynchus [58], which are most likely no competent vectors. In the Middle East, C. imicola is probably the main vector responsible for virus circulation. In Israel, AKAV was repeatedly detected in this vector species by RT-PCR, and in Oman, the isolation of AKAV was possible from this culicoid species [96,97]. Also, throughout Africa, C. imicola seems to be an important vector of AKAV. The virus was isolated multiple times from C. imicola in Zimbabwe [98], and in South Africa AKAV was detected in a pool of mixed Culicoides spp. mainly consisting of C. imicola [99]. Another vector could be C. milnei, as AKAV was isolated from this species in Zimbabwe [98]. In Kenia, AKAV was isolated from Anopheles funestus mosquitoes [100], but true vector competence has not been demonstrated yet.

To investigate the vector competence of midges for $\mathrm{AKAV}$, some experimental infection studies were carried out with different Culicoides species. It could be demonstrated that AKAV replicates in C. variipennis after oral infection for at least 9 days, while in C. nubeculosus, AKAV replicated only after intrathoracic inoculation [101]. The extensive replication of AKAV within C. variipennis suggests that Culicoides spp. can act as fully competent vectors. However, although C. variipennis serving as a suitable surrogate model, this laboratory-adapted species is not the natural vector of the virus, as it is native to North America while AKAV is endemic in Asia, Africa, and Australia.

\subsubsection{SBV}

SBV emerged in late 2011 in the German/Dutch border region [79] and is now endemic in most European countries $[50,102]$. It predominantly infects ruminants, causing a mild, transient disease in adult animals, but it may induce severe fetal malformation when naïve dams are infected during a critical period of pregnancy [103]. Based on its close relationship to AKAV, it was assumed that $C$ ulicoides act as vectors also for SBV and, indeed, SBV genome was subsequently detected in field-collected Culicoides midges of various species repeatedly throughout Europe [104-108]. In contrast, mosquitoes do not seem to play a major role, if any, in virus transmission [109-112].

In temperate European countries, biting midges of the $C$. obsoletus complex are considered the main vectors, while in Mediterranean countries C. imicola and C. punctatus seem to significantly contribute to virus transmission. Viral genome was also detected in C. dewulfi, C. pulicaris, C. newsteadi, C. lupicaris, and C. nubeculosus by (real-time) RT-PCR [104-108,112-114]. To underpin the findings in field-collected biting midges with experimental data, several vector competence studies were carried out. The Nearctic species C. sonorensis was infected orally and intrathoracically. The detection of viral genome after an extrinsic incubation period in the saliva and the isolation of infectious virus from the head proved dissemination of SBV within the insect organism [115] and demonstrated that C. sonorensis is a suitable laboratory model for SBV. Furthermore, from these infected individuals, a range of Cq-values from decapitated heads (including salivary glands) was available to compare with those produced from heads of field-collected Culicoides. The values provided for field-collected $C$. obsoletus, C. scoticus and C. chiopterus from the Netherlands were very similar to those obtained from 
the laboratory infections, indicating that these species act as true vectors [115]. In contrast, multiple infection studies with laboratory colonies of $C$. nubeculosus showed only low infection rates, although viral genome was detected in field-collected C. nubeculosus [112,115].

Unfortunately, for the $C$. obsoletus complex, which consists of the species $C$. obsoletus, $C$. scoticus, $C$. chiopterus and C. montanus and is considered to contain the major vectors of SBV in temperate European countries, laboratory colonies are not available. However, experimental laboratory infection studies were carried out with field-collected individuals of the C. obsoletus complex and with C. imicola, which, according to field data, is considered the main vector in the Mediterranean. Both, i.e., midges of the $C$. obsoletus complex and C. imicola, showed high infection rates and virus dissemination [116], confirming the assumptions of their vector competence, and field-collected C. scoticus were able to replicate SBV to a potentially transmissible level [112].

\subsubsection{SHUV}

SHUV was firstly isolated in Nigeria from healthy cattle [60] as well as from Culicoides biting midges and mosquitoes in Africa [117]. In 2014, SHUV was for the first time detected outside of Africa, and was isolated from malformed lambs in Israel [118]. In addition to typical Simbu virus-related congenital defects in cattle and sheep, SHUV may occasionally induce severe neurological symptoms in horses or cattle $[119,120]$. A general zoonotic potential cannot be ruled out, since SHUV was isolated from a febrile child in Nigeria [121], and specific antibodies were found in large animal veterinarians in South Africa [122].

In South Africa, SHUV was recovered twice from pools of Culex theileri [117]. However, the mosquito taxa Culex pipiens biotype pipiens and Aedes aegypti showed only very low susceptibility to SHUV following intrathoracic inoculation. Oral infection was not possible under experimental conditions [9]. In contrast, C. nubeculosus and C. sonorensis could be orally infected, with the virus disseminating well in both species [9], indicating that Culicoides biting midges are more likely the natural vectors than mosquitoes.

\subsubsection{OROV}

First discovered in a febrile forest worker in 1955 in Trinidad [74], OROV is now endemic in many South and Central American countries [123,124]. Oropouche fever is an acute febrile illness that affects humans. Common symptoms include fever, headache, muscle pain and skin rash, and many infections develop into meningitis or encephalitis [123]. With this zoonotic potential, OROV protrudes from the other viruses in the Simbu serogroup. In South and Central America, OROV occurs in a sylvatic cycle between its insect vectors, some wild bird species and mammals such as rodents, sloths and non-human primates as amplifying hosts (Table 1). In the urban cycle, humans are most likely the only vertebrate hosts, as domestic animals such as chickens, dogs or cats could be excluded as amplifying hosts $[124,125]$.

The main vector in the sylvatic cycle is still unclear; however, OROV was isolated from two sylvatic mosquitoes in the forest: Aedes serratus, collected in the Brazilian Amazon region, and Coquillettidia venezuelensis in Trinidad [125,126].

In the urban cycle, the biting midge species $C$. paraensis and the mosquito Culex quinquefasciatus are believed to be the main vectors. Although the isolation rate from C. paraensis during epidemics is low, its involvement as a vector is suggested based on transmission studies, where C. paraensis transmitted OROV to hamsters five or more days after feeding on blood of viremic patients [125].

Likewise, Culex quinquefasciatus proved to be an ineffective vector of OROV in laboratory transmission experiments [127], but virus is frequently detected in this species during outbreaks [128]. The link between the two transmission cycles, i.e., the sylvatic and the urban cycle, are probably humans entering the forests, where they become infected, and returning to urbanized areas [125]. 


\subsubsection{Further Members of the Simbu Serogroup}

There are several additional members of veterinary importance within the Simbu serogroup (Table 1), which might induce the typical congenital malformation when naïve pregnant dams are infected. Unfortunately, vector competence studies are missing for most of them. However, in general, certain biting midge species are suspected to be able to transmit several members of the serogroup. As an example, field-collected C. brevitarsis, the major vector for AKAV in Australia, were tested positive for further Australian simbuviruses such as Douglas virus (DOUV) or Peaton virus (PEAV) [59,77]. In the Mediterranean and the Middle East, where C. imicola is the main vector of SBV or AKAV, also PEAV was found in this species [129], confirming the concept of certain Culicoides species transmitting several simbuviruses present in the respective region.

\subsection{Further Orthobunyaviruses of Public Health Importance}

In the California encephalitis serogroup of the genus Orthobunyavirus, several zoonotic agents distributed in North America, Europe, Africa, or Asia can be found. However, for none of them Culicoides spp. have been demonstrated to be vector-competent. Since they are transmitted by mosquitoes between their vertebrate hosts, which range from small mammals to ungulates and humans, they are among the viruses that are referred to as "mobovirus" (= mosquito-borne viruses) [130]. Some of the most relevant representatives of zoonotic orthobunyaviruses include LACV, Jamestown Canyon virus (JCV), Keystone virus (KEYV) and Ťahyňa virus (TAHV).

LACV, the most pathogenic agent within the California encephalitis serogroup, is the causative agent of the so-called "rural encephalitis" in the Appalachian and midwestern regions of North America and the leading cause of pediatric arboviral encephalitis. Clinical symptoms of an LACV-infection include headache, fever, myalgia, and encephalitis, while in rare cases fatalities may occur (reviewed in [131]). Within the natural infection cycle between small mammals and mosquito vectors, humans are considered as dead-end hosts, meaning that the virus is not transmitted from humans to blood-feeding insects and that, consequently, the transmission chain ends in human beings [132]. As LACV was isolated multiple times from Aedes triseriatus [133-135] this mosquito species, which is native to North America, is considered the main insect vector. Furthermore, LACV has been isolated from the invasive Asian tiger mosquito Aedes albopictus [136,137] and the Asian bush mosquito Aedes japonicus [138,139]. In experimental infection studies, both proved to be competent vectors of LACV $[140,141]$. To date, this virus has not been found in midges, suggesting that these do not play an important role in transmission.

Similar to LACV, JCV has a wide geographical distribution throughout North America and causes a mild febrile illness or central nervous system infections inducing meningitis or meningoencephalitis in humans [142]. However, in contrast to LACV, which is associated with clinical disease in children, JCV induces symptoms also in adults. White-tailed deer and other ungulates are considered the primary vertebrate hosts [143]. The first virus isolation succeeded from a pool of Aedes abserratus [144]. Since then, JCV has been found in varying but great numbers of different species of Culicidae (Aedes spp., Anopheles spp., Culiseta spp., Psorophora spp.) and Tabanidae (Chrysops spp., Hybomitra spp.) [145]. In the US state of Connecticut, the predominant vector species seems to be Aedes canadensis, while in northeastern New York and in Michigan, JCV is predominantly transmitted by Aedes provocans [146,147]. Aedes intrudens, Aedes abserratus and Aedes punctor seem to be important vectors in Massachusetts [148], Aedes stimulans in northern Indiana [149], and Aedes vexans in North Dakota [150].

KEYV is distributed on the east coast of North America from Florida, where the virus was firstly discovered in 1964 from Aedes atlanticus in Keystone [151], up to Maryland in the north and Texas in the west. Vertebrate hosts seem to be mammals such as squirrels, raccoons, and white-tailed deer [152-154], while the main insect vectors are mosquitoes such as Aedes atlanticus [155], various Aedes spp. (e.g., vexans, tiseriatus, taeniorhynchus, infirmatus, canadensis), and some Culex spp. [156]. In humans, antibodies against KEYV have been repeatedly detected [157], and the virus itself was isolated from individuals showing clinical symptoms such as fever and rash [158]. 
TAHV is endemic in Asia and throughout Africa and represents the first mobovirus pathogenic to humans found in Europe [130]. It may induce a febrile illness referred to as Valtice fever, which occurs mainly in children and is characterized by influenza-like symptoms. In rare cases, it may cause meningitis or atypical pneumonia [159]. Vertebrate hosts other than humans are small mammals such as rabbits or hedgehogs $[160,161]$. Arthropod vectors are most likely mosquitoes of the genera Aedes, Culex, and Anopheles; however, experimental vector competence studies are again missing. Originally, TAHV was isolated from Aedes vexans and Aedes caspius mosquitoes in the villages Ťahyña and Križany, Czechoslovakia [162]. Following its initial discovery, TAHV has been isolated from several mosquito species such as Aedes vexans, Aedes cantans, Aedes caspius, Aedes sticticus, Aedes diantaeus, Aedes hexodontus, Culex pipiens and Anopheles hyrcanus throughout Europe [163-169].

\section{Responses to Culicoides-borne Arbovirus Incursions}

Since treatment options are not available for Culicoides-borne arbovirus infections, other possibilities are discussed to prevent clinical disease in vertebrate hosts and virus spread into unaffected regions. Trading and movement restrictions are put in place for livestock and their products (e.g., semen, embryos) to reduce the risk of virus introductions into new areas [22,103]. For Culicoides-borne diseases with teratogenic effects such as AKAV, SBV, or SHUV, livestock-management measures could be effective. The mating period of livestock could be adjusted to avoid that naïve females are in the critical phase of pregnancy during the season of the highest biting midge activity. Another possibility is to ensure that dams acquire immunity before they conceive for the first time, which could be achieved by exposing the youngstock to potentially infected vectors. However, this concept requires a high number of infected insect organisms every year and a very high transmission rate of the virus from the vector to the vertebrate host to ensure that every young animal is bitten and infected. Hence, a much more reliable method to acquire immunity is by vaccination [50]. For some of the livestock-affecting simbuviruses including AKAV, AINOV, and SBV, vaccines are commercially available [170-173], and European experiences during the bluetongue outbreak from 2006 to 2009 demonstrated that vaccination campaigns against a Culicoides-borne disease can play a major role in reducing virus circulation or even in eradicating the disease from a given region $[174,175]$. For the zoonotic OROV, however, there is no vaccine available yet [176].

From the entomological point of view, the application of insecticides or repellents could be taken into consideration to prevent vectors from biting susceptible animals. In addition, these could be housed in insect-proof (e.g., screened) stable buildings. However, most of these measures seem unhandy, expensive, impracticable and have either none or only limited effect $[177,178]$. For humans with transient exposure, the use of repellents is a suitable measure to protect themselves from insect bites; $N, N$-diethyl-m-toluamide (DEET) is considered the gold standard repellent $[177,179]$.

In addition, measures controlling vector development should be considered. These may include environmental interventions to remove larval breeding sites and the control of adult midges by residual insecticide spraying of surfaces where adult biting midges rest within animal stables. However, due to the broad range of habitats and breeding sites used by biting midges, insecticide treatment and removal of breeding sites are of limited success in biting midge control [177].

In conclusion, Culicoides-borne diseases are difficult to control by vector management alone, while vaccinating livestock may represents an effective tool for disease prevention or even for eradicating a disease from a region.

\section{Concluding Remarks}

For veterinary medicine and veterinary public health, Culicoides biting midges are of great importance as they transmit a multitude of viruses of great impact. In contrast, they only seem to play a minor role for human public health. Due to their potential to contribute to unexpected disease emergence they should be thoroughly surveyed. Multiple detections of novel viruses or introductions 
of known pathogens into previously unaffected regions during the past decade demonstrate in an impressive fashion that arbovirus outbreaks are hard to predict in space and time [180].

From the genus Orthobunyavirus, the emergence of SBV in Europe or the incursion of SHUV into the Middle East are prominent examples [79,118]. To be prepared for putative future outbreaks of arboviral diseases, it is critical to carry out profound research and surveillance on biting midges and their role as vectors.

Author Contributions: Conceptualization, M.B. and K.W.; methodology, F.S. and K.W.; writing—original draft preparation, F.S. and K.W.; writing-review and editing, H.K. and M.B; visualization, F.S. and K.W.; all authors read and approved the final version of the manuscript.

Funding: This research was funded by the German Federal Ministry of Food and Agriculture (BMEL) through the Federal Office for Agriculture and Food (BLE), grant number 281 B101816.

Conflicts of Interest: The authors declare no conflict of interest. The funders had no role in the design of the study; in the collection, analyses, or interpretation of data; in the writing of the manuscript, or in the decision to publish the results.

\section{References}

1. Baud, D.; Gubler, D.J.; Schaub, B.; Lanteri, M.C.; Musso, D. An update on Zika virus infection. Lancet 2017, 390, 2099-2109. [CrossRef]

2. Petersen, L.R.; Brault, A.C.; Nasci, R.S. West Nile virus: Review of the literature. JAMA 2013, 310, 308-315. [CrossRef]

3. Young, P.R. Arboviruses: A family on the move. Adv. Exp. Med. Biol. 2018, 1062, 1-10. [PubMed]

4. Althouse, B.M.; Hanley, K.A. The tortoise or the hare? Impacts of within-host dynamics on transmission success of arthropod-borne viruses. Philos. Trans. R. Soc. Lond. B Biol. Sci. 2015, 370, 20140299. [CrossRef] [PubMed]

5. Medlock, J.M.; Leach, S.A. Effect of climate change on vector-borne disease risk in the UK. Lancet Infect. Dis. 2015, 15, 721-730. [CrossRef]

6. Hubálek, Z.; Rudolf, I.; Nowotny, N. Arboviruses pathogenic for domestic and wild animals. Adv. Virus Res. 2014, 89, 201-275.

7. ICTV. Virus Taxonomy: The Classification and Nomenclature of Viruses. Available online: https:/talk. ictvonline.org/ictv-reports/ictv_online_report/ (accessed on 25 March 2019).

8. Beerntsen, B.T.; James, A.A.; Christensen, B.M. Genetics of mosquito vector competence. Microbiol. Mol. Biol. Rev. 2000, 64, 115-137. [CrossRef] [PubMed]

9. Möhlmann, T.W.R.; Oymans, J.; Wichgers Schreur, P.J.; Koenraadt, C.J.M.; Kortekaas, J.; Vogels, C.B.F. Vector competence of biting midges and mosquitoes for Shuni virus. PLoS Negl. Trop. Dis. 2018, 12, e0006993. [CrossRef]

10. Borkent, A. Numbers of Extant and Fossil Species of Ceratopogonidae. 6 July 2016. Available online: https://www.inhs.illinois.edu/files/4014/6785/5847/WorldCatalogtaxa.pdf (accessed on 25 March 2019).

11. Mellor, P.S.; Boorman, J.; Baylis, M. Culicoides biting midges: Their role as arbovirus vectors. Annu. Rev. Entomol. 2000, 45, 307-340. [CrossRef]

12. Mathieu, B.; Cêtre-Sossah, C.; Garros, C.; Chavernac, D.; Balenghien, T.; Carpenter, S.; Setier-Rio, M.L.; Vignes-Lebbe, R.; Ung, V.; Candolfi, E.; et al. Development and validation of IIKC: An interactive identification key for Culicoides (Diptera: Ceratopogonidae) females from the western Palaearctic region. Parasit. Vectors 2012, 5, 137. [CrossRef]

13. Pages, N.; Sarto, I.M.V. Differentiation of Culicoides obsoletus and Culicoides scoticus (Diptera: Ceratopogonidae) based on mitochondrial cytochrome oxidase subunit I. J. Med. Entomol. 2005, 42, 1026-1034. [CrossRef]

14. Dallas, J.F.; Cruickshank, R.H.; Linton, Y.M.; Nolan, D.V.; Patakakis, M.; Braverman, Y.; Capela, R.; Capela, M.; Pena, I.; Meiswinkel, R.; et al. Phylogenetic status and matrilineal structure of the biting midge, Culicoides imicola, in Portugal, Rhodes and Israel. Med. Vet. Entomol. 2003, 17, 379-387. [CrossRef]

15. Cêtre-Sossah, C.; Mathieu, B.; Setier-Rio, M.L.; Grillet, C.; Baldet, T.; Delécolle, J.C.; Albina, E. Development and evaluation of a real-time quantitative PCR assay for Culicoides imicola, one of the main vectors of bluetongue (BT) and African horse sickness (AHS) in Africa and Europe. Res. Vet. Sci. 2008, 85, 372-382. [CrossRef] 
16. Wenk, C.E.; Kaufmann, C.; Schaffner, F.; Mathis, A. Molecular characterization of Swiss Ceratopogonidae (Diptera) and evaluation of real-time PCR assays for the identification of Culicoides biting midges. Vet. Parasitol. 2012, 184, 258-266. [CrossRef]

17. Deblauwe, I.; de Witte, J.C.; de Deken, G.; de Deken, R.; Madder, M.; van Erk, S.; Hoza, F.A.; Lathouwers, D.; Geysen, D. A new tool for the molecular identification of Culicoides species of the Obsoletus group: The glass slide microarray approach. Med. Vet. Entomol. 2012, 26, 83-91. [CrossRef]

18. Uhlmann, K.R.; Gibb, S.; Kalkhof, S.; Arroyo-Abad, U.; Schulz, C.; Hoffmann, B.; Stubbins, F.; Carpenter, S.; Beer, M.; von Bergen, M.; et al. Species determination of Culicoides biting midges via peptide profiling using matrix-assisted laser desorption ionization mass spectrometry. Parasit. Vectors 2014, 7, 392. [CrossRef]

19. Wirth, W.W.; Hubert, A.A. The Culicoides of Southeast Asia (Diptera: Ceratopogonidae). Am. Entomol. Inst. (USA) 1989, 44, 514.

20. Kline, D.L.; Axtell, R.C. Salt-marsh Culicoides (Diptera-Ceratopogonidae)—Species, seasonal abundance and comparisons of trapping methods. Mosq. News 1976, 36, 1-10.

21. Van der Rijt, R.; van den Boom, R.; Jongema, Y.; van Oldruitenborgh-Oosterbaan, M.M. Culicoides species attracted to horses with and without insect hypersensitivity. Vet. J. 2008, 178, 91-97. [CrossRef]

22. Carpenter, S.; Groschup, M.H.; Garros, C.; Felippe-Bauer, M.L.; Purse, B.V. Culicoides biting midges, arboviruses and public health in Europe. Antiviral Res. 2013, 100, 102-113. [CrossRef]

23. Veiga, J.; Martinez-de la Puente, J.; Vaclav, R.; Figuerola, J.; Valera, F. Culicoides paolae and C. circumscriptus as potential vectors of avian haemosporidians in an arid ecosystem. Parasit. Vectors 2018, 11, 524. [CrossRef]

24. Chagas, C.R.F.; Bukauskaite, D.; Ilgunas, M.; Iezhova, T.; Valkiunas, G. A new blood parasite of leaf warblers: Molecular characterization, phylogenetic relationships, description and identification of vectors. Parasit. Vectors 2018, 11, 538. [CrossRef]

25. Yates, J.A.; Lowrie, R.C., Jr.; Eberhard, M. Development of Tetrapetalonema llewellyni to the infective stage in Culicoides hollensis. J. Parasitol. 1982, 68, 293-296. [CrossRef]

26. Lowrie, R.C., Jr.; Eberhard, M.L.; Orihel, T.C. Development of Tetrapetalonema marmosetae to the infective stage in Culicoides hollensis and C. furens. J. Parasitol. 1978, 64, 1003-1007. [CrossRef]

27. Linley, J.R. Biting midges (Diptera: Ceratopogonidae) as vectors of nonviral animal pathogens. J. Med. Entomol. 1985, 22, 589-599. [CrossRef]

28. Meiswinkel, R.; Nevill, E.M.; Venter, G.J. Vectors: Culicoides spp. In Infectious Diseases of Livestock with Special Reference to Southern Africa; Coetzer, J.A.W., Thomson, G.R., Tustin, R.C., Eds.; Oxford University Press: Cape Town, South Africa, 1994; Volume 1, pp. 68-89.

29. Carpenter, S.; Veronesi, E.; Mullens, B.; Venter, G. Vector competence of Culicoides for arboviruses: Three major periods of research, their influence on current studies and future directions. Rev. Sci. Tech. 2015, 34, 97-112. [CrossRef]

30. Jennings, M.; Platt, G.S.; Bowen, E.T. The susceptibility of Culicoides variipennis Coq. (Diptera: Ceratopogonidae) to laboratory infection with Rift Valley fever virus. Trans. R. Soc. Trop. Med. Hyg. 1982, 76, 587-589. [CrossRef]

31. Carpenter, S.; Szmaragd, C.; Barber, J.; Labuschagne, K.; Gubbins, S.; Mellor, P. An assessment of Culicoides surveillance techniques in northern Europe: Have we underestimated a potential bluetongue virus vector? J. Appl. Ecol. 2008, 45, 1237-1245.

32. Murray, M.D. Local dispersal of the biting midge Culicoides brevitarsis Kieffer (Diptera, Ceratopogonidae) in Southeastern Australia. Austr. J. Zool. 1987, 35, 559-573. [CrossRef]

33. Murray, M.D.; Nix, H.A. Southern limits of distribution and abundance of the biting-midge Culicoides brevitarsis Kieffer (Diptera, Ceratopogonidae) in Southeastern Australia-An application of the Growest Model. Austr. J. Zool. 1987, 35, 575-585. [CrossRef]

34. Kirkland, P.D. Akabane virus infection. Rev. Sci. Tech. 2015, 34, 403-410. [CrossRef]

35. Sellers, R.F. Weather, host and vector-Their interplay in the spread of insect-borne animal virus diseases. J. Hyg. (London) 1980, 85, 65-102. [CrossRef]

36. Sellers, R.F.; Maarouf, A.R. Possible introduction of epizootic hemorrhagic disease of deer virus (serotype 2) and bluetongue virus (serotype 11) into British Columbia in 1987 and 1988 by infected Culicoides carried on the wind. Can. J. Vet. Res. 1991, 55, 367-370.

37. Sellers, R.F.; Pedgley, D.E. Possible windborne spread to western Turkey of bluetongue virus in 1977 and of Akabane virus in 1979. J. Hyg. (London) 1985, 95, 149-158. [CrossRef] 
38. Braverman, Y.; Chechik, F. Air streams and the introduction of animal diseases borne on Culicoides (Diptera, Ceratopogonidae) into Israel. Rev. Sci. Tech. 1996, 15, 1037-1052. [CrossRef]

39. Hunt, G.J. A Procedural Manual for the Large-Scale Rearing of the Biting Midge, Culicoides variipennis (Diptera: Ceratopogonidae); U.S. Department of Agriculture, National Agricultural Library (USA): Beltsville, MD, USA, 1994.

40. Carpenter, S.; Mordue, A.J.; Mordue, W. Oviposition in Culicoides impunctatus under laboratory conditions. Entomol. Exp. Appl. 2001, 101, 123-129. [CrossRef]

41. Jones, R.H.; Foster, N.M. Relevance of laboratory colonies of the vector in arbovirus research-Culicoides variipennis and bluetongue. Am. J. Trop. Med. Hyg. 1978, 27, 168-177. [CrossRef]

42. Maes, P.; Alkhovsky, S.V.; Bao, Y.; Beer, M.; Birkhead, M.; Briese, T.; Buchmeier, M.J.; Calisher, C.H.; Charrel, R.N.; Choi, I.R.; et al. Taxonomy of the family Arenaviridae and the order Bunyavirales: update 2018. Arch. Virol. 2018, 163, 2295-2310. [CrossRef]

43. Barr, J.N.; Walter, C.T. Recent advances in the molecular and cellular biology of bunyaviruses. J. Gen. Virol. 2011, 92, 2467-2484.

44. Shi, X.; Lappin, D.F.; Elliott, R.M. Mapping the Golgi targeting and retention signal of Bunyamwera virus glycoproteins. J. Virol. 2004, 78, 10793-10802. [CrossRef]

45. Shi, X.; van Mierlo, J.T.; French, A.; Elliott, R.M. Visualizing the replication cycle of Bunyamwera orthobunyavirus expressing fluorescent protein-tagged Gc glycoprotein. J. Virol. 2010, 84, 8460-8469. [CrossRef] [PubMed]

46. Shi, X.; Goli, J.; Clark, G.; Brauburger, K.; Elliott, R.M. Functional analysis of the Bunyamwera orthobunyavirus Gc glycoprotein. J. Gen. Virol. 2009, 90, 2483-2492. [CrossRef]

47. Elliott, R.M. Orthobunyaviruses: Recent genetic and structural insights. Nat. Rev. Microbiol. 2014, 12, 673-685. [CrossRef] [PubMed]

48. Elliott, R.M.; Blakqori, G. Molecular biology of orthobunyaviruses. In Bunyaviridae. Molecular and Cellular Biology; Plyusnin, A., Elliott, R.M., Eds.; Caister Academic Press: Norfolk, UK, 2011; pp. 1-39.

49. Shi, X.; Kohl, A.; Léonard, V.H.J.; Li, P.; McLees, A.; Elliott, R.M. Requirement of the N-terminal region of Orthobunyavirus nonstructural protein NSm for virus assembly and morphogenesis. J. Virol. 2006, 80, 8089. [CrossRef]

50. Wernike, K.; Beer, M. Schmallenberg virus: A novel virus of veterinary importance. Adv. Virus Res. 2017, 99, 39-60. [PubMed]

51. Kato, T.; Shirafuji, H.; Tanaka, S.; Sato, M.; Yamakawa, M.; Tsuda, T.; Yanase, T. Bovine arboviruses in Culicoides biting midges and sentinel cattle in southern Japan from 2003 to 2013. Transbound. Emerg. Dis. 2016, 63, e160-e172. [CrossRef]

52. Kato, T.; Yanase, T.; Suzuki, M.; Katagiri, Y.; Ikemiyagi, K.; Takayoshi, K.; Shirafuji, H.; Ohashi, S.; Yoshida, K.; Yamakawa, M.; et al. Monitoring for bovine arboviruses in the most southwestern islands in Japan between 1994 and 2014. BMC Vet. Res. 2016, 12, 125. [CrossRef]

53. Hayama, Y.; Yanase, T.; Suzuki, M.; Unten, K.; Tomochi, H.; Kakehi, M.; Shono, Y.; Yamamoto, T.; Kobayashi, S.; Murai, K.; et al. Meteorological factors affecting seroconversion of Akabane disease in sentinel calves in the subtropical Okinawa Islands of Japan. Trop. Anim. Health Prod. 2018, 50, 209-215. [CrossRef]

54. Wernike, K.; Holsteg, M.; Szillat, K.P.; Beer, M. Development of within-herd immunity and long-term persistence of antibodies against Schmallenberg virus in naturally infected cattle. BMC Vet. Res. 2018, 14, 368. [CrossRef]

55. Geoghegan, J.L.; Walker, P.J.; Duchemin, J.B.; Jeanne, I.; Holmes, E.C. Seasonal drivers of the epidemiology of arthropod-borne viruses in Australia. PLoS Negl. Trop. Dis. 2014, 8, e3325. [CrossRef]

56. Wernike, K.; Elbers, A.; Beer, M. Schmallenberg virus infection. Rev. Sci. Tech. 2015, 34, 363-373. [CrossRef]

57. Saeed, M.F.; Li, L.; Wang, H.; Weaver, S.C.; Barrett, A.D. Phylogeny of the Simbu serogroup of the genus Bunyavirus. J. Gen. Virol. 2001, 82, 2173-2181. [CrossRef]

58. Oya, A.; Okuno, T.; Ogata, T.; Kobayashii; Matsuyama, T. Akabane, a new arbovirus isolated in Japan. Jpn. J. Med. Sci. Biol. 1961, 14, 101-108. [CrossRef]

59. Cybinski, D.H. Douglas and Tinaroo viruses: Two Simbu group arboviruses infecting Culicoides brevitarsis and livestock in Australia. Aust. J. Biol. Sci. 1984, 37, 91-97. [CrossRef] 
60. Causey, O.R.; Kemp, G.E.; Causey, C.E.; Lee, V.H. Isolations of Simbu-group viruses in Ibadan, Nigeria 1964-69, including the new types Sango, Shamonda, Sabo and Shuni. Ann. Trop. Med. Parasitol. 1972, 66, 357-362. [CrossRef]

61. Takahashi, K.; Oya, A.; Okazda, T.; Matsuo, R.; Kuma, M. Aino virus, a new member of Simbu group of arbovirus from mosquitoes in Japan. Jpn. J. Med. Sci. Biol. 1968, 21, 95-101. [CrossRef]

62. Reeves, W.C.; Scrivani, R.P.; Hardy, J.L.; Roberts, D.R.; Nelson, R.L. Buttonwillow virus, a new Arbovirus isolated from mammals and Culicoides midges in Kern County, California. Am. J. Trop. Med. Hyg. 1970, 19, 544-551. [CrossRef]

63. Bryant, J.E.; Crabtree, M.B.; Nam, V.S.; Yen, N.T.; Duc, H.M.; Miller, B.R. Isolation of arboviruses from mosquitoes collected in northern Vietnam. Am. J. Trop. Med. Hyg. 2005, 73, 470-473. [CrossRef]

64. Kono, Y.; Yusnita, Y.; Mohd Ali, A.R.; Maizan, M.; Sharifah, S.H.; Fauzia, O.; Kubo, M.; Aziz, A.J. Characterization and identification of Oya virus, a Simbu serogroup virus of the genus Bunyavirus, isolated from a pig suspected of Nipah virus infection. Arch. Virol. 2002, 147, 1623-1630. [CrossRef]

65. Doherty, R.L.; Carley, J.G.; Kay, B.H.; Filippich, C.; Marks, E.N.; Frazier, C.L. Isolation of virus strains from mosquitoes collected in Queensland, 1972-1976. Aust. J. Exp. Biol. Med. Sci. 1979, 57, 509-520. [CrossRef]

66. McIntosh, B.M.; McGillivray, G.M.; Dickinson, D.B. Ingwavuma virus: An arbovirus isolated in South Africa. S. Afr. J. Med. Sci. 1965, 30,67-70.

67. Figueiredo, L.T.; Da Rosa, A.P. Jatobal virus antigenic characterization by ELISA and neutralization test using EIA as indicator, on tissue culture. Mem. Inst. Oswaldo Cruz 1988, 83, 161-164. [CrossRef]

68. Doherty, R.L.; Carley, J.G.; Filippich, C.; Kay, B.H.; Gorman, B.M.; Rajapaksa, N. Isolation of Sindbis (alphavirus) and Leanyer viruses from mosquitoes collected in the Northern Territory of Australia, 1974. Aust. J. Exp. Biol. Med. Sci. 1977, 55, 485-489. [CrossRef]

69. Anderson, C.R.; Spence, L.P.; Downs, W.G.; Aitken, T.H. Manzanilla virus: A new virus isolated from the blood of a howler monkey in Trinidad, W.I. Am. J. Trop. Med. Hyg. 1960, 9, 78-80. [CrossRef] [PubMed]

70. Pajot, F.X. Diseases transmitted by insects in French Guaiana. Bol. Oficina Sanit. Panam. 1980, 88, $218-227$. (In Spanish) [PubMed]

71. Calisher, C.H.; Kokernot, R.H.; De Moore, J.F.; Boyd, K.R.; Hayes, J.; Chappell, W.A. Arbovirus studies in the Ohio-Mississippi Basin, 1964-1967. VI. Mermet: A Simbu-group arbovirus. Am. J. Trop. Med. Hyg. 1969, 18, 779-788. [CrossRef] [PubMed]

72. Aguilar, P.V.; Barrett, A.D.; Saeed, M.F.; Watts, D.M.; Russell, K.; Guevara, C.; Ampuero, J.S.; Suarez, L.; Cespedes, M.; Montgomery, J.M.; et al. Iquitos virus: A novel reassortant Orthobunyavirus associated with human illness in Peru. PLoS Negl. Trop. Dis. 2011, 5, e1315. [CrossRef] [PubMed]

73. Ladner, J.T.; Savji, N.; Lofts, L.; Travassos da Rosa, A.; Wiley, M.R.; Gestole, M.C.; Rosen, G.E.; Guzman, H.; Vasconcelos, P.F.; Nunes, M.R.; et al. Genomic and phylogenetic characterization of viruses included in the Manzanilla and Oropouche species complexes of the genus Orthobunyavirus, family Bunyaviridae. J. Gen. Virol. 2014, 95, 1055-1066. [CrossRef] [PubMed]

74. Anderson, C.R.; Spence, L.; Downs, W.G.; Aitken, T.H. Oropouche virus: A new human disease agent from Trinidad, West Indies. Am. J. Trop. Med. Hyg. 1961, 10, 574-578. [CrossRef]

75. Tilston-Lunel, N.L.; Hughes, J.; Acrani, G.O.; da Silva, D.E.; Azevedo, R.S.; Rodrigues, S.G.; Vasconcelos, P.F.; Nunes, M.R.; Elliott, R.M. Genetic analysis of members of the species Oropouche virus and identification of a novel M segment sequence. J. Gen. Virol. 2015, 96, 1636-1650. [CrossRef]

76. Seymour, C.; Peralta, P.H.; Montgomery, G.G. Viruses isolated from Panamanian sloths. Am. J. Trop. Med. Hyg. 1983, 32, 1435-1444. [CrossRef] [PubMed]

77. St George, T.D.; Standfast, H.A.; Cybinski, D.H.; Filippich, C.; Carley, J.G. Peaton virus: A new Simbu group arbovirus isolated from cattle and Culicoides brevitarsis in Australia. Aust. J. Biol. Sci. 1980, 33, 235-243. [CrossRef] [PubMed]

78. Dandawate, C.N.; Rajagopalan, P.K.; Pavri, K.M.; Work, T.H. Virus isolations from mosquitoes collected in North Arcot district, Madras state, and Chittoor district, Andhra Pradesh between November 1955 and October 1957. Indian J. Exp. Biol. 1969, 57, 1420-1426.

79. Hoffmann, B.; Scheuch, M.; Höper, D.; Jungblut, R.; Holsteg, M.; Schirrmeier, H.; Eschbaumer, M.; Goller, K.V.; Wernike, K.; Fischer, M.; et al. Novel orthobunyavirus in cattle, Europe, 2011. Emerg. Infect. Dis. 2012, 18, 469-472. [CrossRef] [PubMed] 
80. Rodrigues, F.M.; Singh, P.B.; Dandawate, C.N.; Soman, R.S.; Bhatt, P.N. Kaikalur virus-A new arthropod-borne virus belonging to the Simbu group isolated in India from Culex tritaeniorhynchus (Giles). Indian J. Med. Res. 1977, 66, 719-725.

81. Mitchell, C.J.; Monath, T.P.; Sabattini, M.S.; Cropp, C.B.; Daffner, J.F.; Calisher, C.H.; Jakob, W.L.; Christensen, H.A. Arbovirus investigations in Argentina, 1977-1980. II. Arthropod collections and virus isolations from Argentine mosquitoes. Am. J. Trop. Med. Hyg. 1985, 34, 945-955. [CrossRef] [PubMed]

82. Weinbren, M.P.; Heymann, C.S.; Kokernot, R.H.; Paterson, H.E. Studies on arthropod-borne viruses of Tongaland. VII. Simbu virus, a hitherto unknown agent isolated from Aedes (Banksinella) circumluteolus Theo. S. Afr. J. Med. Sci. 1957, 22, 93-102. [PubMed]

83. Carey, D.E.; Reuben, R.; George, S.; Shope, R.E.; Myers, R.M. Kammavanpettai, Kannamangalam, Sembalam and Thimiri viruses: Four unrelated new agents isolated from birds in India. Indian J. Med. Res. 1971, 59, 1708-1711.

84. Shope, R.E.; Paes de Andrade, A.H.; Bensabath, G. The serological response of animals to virus infection in Utinga Forest, Belem, Brazil. Atas Simp 1967, 243, 225-230.

85. Oğuzoğlu, T.C.; Toplu, N.; Koc, B.T.; Dogan, F.; Epikmen, E.T.; Ipek, E.; Akkoc, A.N. First molecular detection and characterization of Akabane virus in small ruminants in Turkey. Arch. Virol. 2015, 160, 2623-2627. [CrossRef]

86. Golender, N.; Bumbarov, V.Y.; Erster, O.; Beer, M.; Khinich, Y.; Wernike, K. Development and validation of a universal S-segment-based real-time RT-PCR assay for the detection of Simbu serogroup viruses. J. Virol. Methods 2018, 261, 80-85. [CrossRef]

87. Oem, J.K.; Lee, K.H.; Kim, H.R.; Bae, Y.C.; Chung, J.Y.; Lee, O.S.; Roh, I.S. Bovine epizootic encephalomyelitis caused by Akabane virus infection in Korea. J. Comp. Pathol. 2012, 147, 101-105. [CrossRef]

88. Oem, J.K.; Yoon, H.J.; Kim, H.R.; Roh, I.S.; Lee, K.H.; Lee, O.S.; Bae, Y.C. Genetic and pathogenic characterization of Akabane viruses isolated from cattle with encephalomyelitis in Korea. Vet. Microbiol. 2012, 158, 259-266. [CrossRef]

89. Miyazato, S.; Miura, Y.; Hase, M.; Kubo, M.; Goto, Y.; Kono, Y. Encephalitis of cattle caused by Iriki isolate, a new strain belonging to Akabane virus. Nihon Juigaku Zasshi 1989, 51, 128-136. [CrossRef]

90. Charles, J.A. Akabane virus. Vet. Clin. North Am. Food Anim. Pract. 1994, 10, 525-546. [CrossRef]

91. St George, T.D.; Standfast, H.A.; Cybinski, D.H. Isolations of Akabane virus from sentinel cattle and Culicoides brevitarsis. Aust. Vet. J. 1978, 54, 558-561. [CrossRef]

92. Cybinski, D.H.; St George, T.D.; Paull, N.I. Antibodies to Akabane virus in Australia. Aust. Vet. J. 1978, 54, 1-3. [CrossRef]

93. St George, T.D.; Standfast, H.A. Diseases caused by Akabane and related Simbu-group viruses. In Infectious Diseases of Livestock with Special Reference to Southern Africa; Coetzer, J.A.W., Thomson, G.R., Tustin, R.C., Eds.; Oxford University Press: Cape Town, South Africa, 1994; Volume 1, pp. 681-687.

94. Cybinski, D.H.; Muller, M.J. Isolation of arboviruses from cattle and insects at two sentinel sites in Queensland, Australia, 1979-1985. Austr. J. Zool. 1990, 38, 25-32. [CrossRef]

95. Kurogi, H.; Akiba, K.; Inaba, Y.; Matumoto, M. Isolation of Akabane virus from the biting midge Culicoides oxystoma in Japan. Vet. Microbiol. 1987, 15, 243-248. [CrossRef]

96. Stram, Y.; Brenner, J.; Braverman, Y.; Banet-Noach, C.; Kuznetzova, L.; Ginni, M. Akabane virus in Israel: A new virus lineage. Virus Res. 2004, 104, 93-97. [CrossRef]

97. Al-Busaidy, S.M.; Mellor, P.S. Isolation and identification of arboviruses from the Sultanate of Oman. Epidemiol. Infect. 1991, 106, 403-413. [CrossRef]

98. Blackburn, N.K.; Searle, L.; Phelps, R.J. Viruses isolated from Culicoides (Diptera: Ceratopogonidae) caught at the veterinary research farm, Mazowe, Zimbabwe. J. Entomol. Soc. South. Afr. 1958, 48, 331-336.

99. Theodoridis, A.; Nevill, E.M.; Els, H.J.; Boshoff, S.T. Viruses isolated from Culicoides midges in South Africa during unsuccessful attempts to isolate bovine ephemeral fever virus. Onderstepoort J. Vet. Res. 1979, 46, 191-198.

100. Metselaar, D.; Robin, Y. Akabane virus isolated in Kenya. Vet. Rec. 1976, 99, 86. [CrossRef] [PubMed]

101. Jennings, M.; Mellor, P.S. Culicoides: Biological vectors of Akabane virus. Vet. Microbiol. 1989, 21, $125-131$. [CrossRef] 
102. EFSA. "Schmallenberg" Virus: Analysis of the Epidemiological Data (May 2013). EFSA Supporting Publications 2013. EN-3429. Available online: http://www.efsa.europa.eu/de/supporting/doc/429e.pdf (accessed on 15 July 2013).

103. EFSA. Schmallenberg virus: State of Art. EFSA J. 2014, 12, 54.

104. De Regge, N.; Deblauwe, I.; De Deken, R.; Vantieghem, P.; Madder, M.; Geysen, D.; Smeets, F.; Losson, B.; van den Berg, T.; Cay, A.B. Detection of Schmallenberg virus in different Culicoides spp. by real-time RT-PCR. Transbound. Emerg. Dis. 2012, 59, 471-475. [CrossRef]

105. Rasmussen, L.D.; Kristensen, B.; Kirkeby, C.; Rasmussen, T.B.; Belsham, G.J.; Bodker, R.; Bøtner, A. Culicoids as vectors of Schmallenberg virus. Emerg. Infect. Dis. 2012, 18, 1204-1206. [CrossRef]

106. Goffredo, M.; Monaco, F.; Capelli, G.; Quaglia, M.; Federici, V.; Catalani, M.; Montarsi, F.; Polci, A.; Pinoni, C.; Calistri, P.; et al. Schmallenberg virus in Italy: A retrospective survey in Culicoides stored during the bluetongue Italian surveillance program. Prev. Vet. Med. 2013, 111, 230-236. [CrossRef]

107. Elbers, A.R.; Meiswinkel, R.; van Weezep, E.; Sloet van Oldruitenborgh-Oosterbaan, M.M.; Kooi, E.A. Schmallenberg virus in Culicoides spp. biting midges, the Netherlands, 2011. Emerg. Infect. Dis. 2013, 19, 106-109. [CrossRef]

108. Larska, M.; Polak, M.P.; Grochowska, M.; Lechowski, L.; Zwiazek, J.S.; Zmudzinski, J.F. First report of Schmallenberg virus infection in cattle and midges in Poland. Transbound. Emerg. Dis. 2013, 60, 97-101. [CrossRef] [PubMed]

109. Wernike, K.; Jöst, H.; Becker, N.; Schmidt-Chanasit, J.; Beer, M. Lack of evidence for the presence of Schmallenberg virus in mosquitoes in Germany, 2011. Parasit. Vectors 2014, 7, 402. [CrossRef] [PubMed]

110. Manley, R.; Harrup, L.E.; Veronesi, E.; Stubbins, F.; Stoner, J.; Gubbins, S.; Wilson, A.; Batten, C.; Koenraadt, C.J.; Henstock, M.; et al. Testing of UK populations of Culex pipiens L. for Schmallenberg virus vector competence and their colonization. PLoS ONE 2015, 10, e0134453. [CrossRef] [PubMed]

111. Scholte, E.J.; Mars, M.H.; Braks, M.; Den Hartog, W.; Ibanez-Justicia, A.; Koopmans, M.; Koenraadt, C.J.; De Vries, A.; Reusken, C. No evidence for the persistence of Schmallenberg virus in overwintering mosquitoes. Med. Vet. Entomol. 2014, 28, 110-115. [CrossRef] [PubMed]

112. Balenghien, T.; Pagès, N.; Goffredo, M.; Carpenter, S.; Augot, D.; Jacquier, E.; Talavera, S.; Monaco, F.; Depaquit, J.; Grillet, C.; et al. The emergence of Schmallenberg virus across Culicoides communities and ecosystems in Europe. Prev. Vet. Med. 2014, 116, 360-369. [CrossRef] [PubMed]

113. Segard, A.; Gardes, L.; Jacquier, E.; Grillet, C.; Mathieu, B.; Rakotoarivony, I.; Setier-Rio, M.L.; Chavernac, D.; Cetre-Sossah, C.; Balenghien, T.; et al. Schmallenberg virus in Culicoides Latreille (Diptera: Ceratopogonidae) populations in France during 2011-2012 outbreak. Transbound. Emerg. Dis. 2018, 65, e94-e103. [CrossRef] [PubMed]

114. Elbers, A.R.; Meiswinkel, R.; van Weezep, E.; Kooi, E.A.; van der Poel, W.H. Schmallenberg virus in Culicoides biting midges in the Netherlands in 2012. Transbound. Emerg. Dis. 2015, 62, 339-342. [CrossRef] [PubMed]

115. Veronesi, E.; Henstock, M.; Gubbins, S.; Batten, C.; Manley, R.; Barber, J.; Hoffmann, B.; Beer, M.; Attoui, H.; Mertens, P.P.; et al. Implicating Culicoides biting midges as vectors of Schmallenberg virus using semi-quantitative RT-PCR. PLoS ONE 2013, 8, e57747. [CrossRef]

116. Pagès, N.; Talavera, S.; Verdún, M.; Pujol, N.; Valle, M.; Bensaid, A.; Pujols, J. Schmallenberg virus detection in Culicoides biting midges in Spain: First laboratory evidence for highly efficient infection of Culicoides of the Obsoletus complex and Culicoides imicola. Transbound. Emerg. Dis. 2018, 65, e1-e6. [CrossRef]

117. McIntosh, B.M.; Jupp, P.G.; De Sousa, J. Further isolations of the arboviruses from mosquitoes collected in Tongaland, South Africa, 1960-1968. J. Med. Entomol. 1972, 9, 155-159. [CrossRef]

118. Golender, N.; Brenner, J.; Valdman, M.; Khinich, Y.; Bumbarov, V.; Panshin, A.; Edery, N.; Pismanik, S.; Behar, A. Malformations caused by Shuni virus in ruminants, Israel, 2014-2015. Emerg. Infect. Dis. 2015, 21, 2267-2268. [CrossRef]

119. Van Eeden, C.; Williams, J.H.; Gerdes, T.G.; van Wilpe, E.; Viljoen, A.; Swanepoel, R.; Venter, M. Shuni virus as cause of neurologic disease in horses. Emerg. Infect. Dis. 2012, 18, 318-321. [CrossRef]

120. Golender, N.; Bumbarov, V.; Assis, I.; Beer, M.; Khinich, Y.; Koren, O.; Edery, N.; Eldar, A.; Wernike, K. Shuni virus in Israel: Neurological disease and fatalities in cattle. Transbound. Emerg. Dis. 2019, in press. [CrossRef] [PubMed] 
121. Moore, D.L.; Causey, O.R.; Carey, D.E.; Reddy, S.; Cooke, A.R.; Akinkugbe, F.M.; David-West, T.S.; Kemp, G.E. Arthropod-borne viral infections of man in Nigeria, 1964-1970. Ann. Trop. Med. Parasitol. 1975, 69, $49-64$. [CrossRef]

122. Van Eeden, C.; Swanepoel, R.; Venter, M. Antibodies against West Nile and Shuni viruses in veterinarians, South Africa. Emerg. Infect. Dis. 2014, 20, 1409-1411. [CrossRef] [PubMed]

123. Romero-Alvarez, D.; Escobar, L.E. Oropouche fever, an emergent disease from the Americas. Microbes Infect. 2018, 20, 135-146. [CrossRef] [PubMed]

124. Travassos da Rosa, J.F.; de Souza, W.M.; Pinheiro, F.P.; Figueiredo, M.L.; Cardoso, J.F.; Acrani, G.O.; Nunes, M.R.T. Oropouche virus: Clinical, epidemiological, and molecular aspects of a neglected Orthobunyavirus. Am. J. Trop. Med. Hyg. 2017, 96, 1019-1030. [PubMed]

125. Pinheiro, F.P.; Travassos da Rosa, A.P.; Travassos da Rosa, J.F.; Ishak, R.; Freitas, R.B.; Gomes, M.L.; LeDuc, J.W.; Oliva, O.F. Oropouche virus. I. A review of clinical, epidemiological, and ecological findings. Am. J. Trop. Med. Hyg. 1981, 30, 149-160. [CrossRef] [PubMed]

126. Pinheiro, F.; Travassos da Rosa, A.; Vasconcelos, P.F. Oropouche fever. In Textbook of Pediatric Infectious Diseases; Feigin, R.D., Ed.; Saunders: Philadelphia, PA, USA, 2004; pp. 2418-2423.

127. Hoch, A.L.; Pinheiro, F.P.; Roberts, D.R.; Gomes, M.L. Laboratory transmission of Oropouche virus by Culex quinquefasciatus Say. Bull. Pan. Am. Health Organ. 1987, 21, 55-61.

128. Cardoso, B.F.; Serra, O.P.; Heinen, L.B.; Zuchi, N.; Souza, V.C.; Naveca, F.G.; Santos, M.A.; Slhessarenko, R.D. Detection of Oropouche virus segment $\mathrm{S}$ in patients and in Culex quinquefasciatus in the state of Mato Grosso, Brazil. Mem. Inst. Oswaldo Cruz 2015, 110, 745-754. [CrossRef]

129. Behar, A.; Leibovich, B.B.; Edery, N.; Yanase, T.; Brenner, J. First genomic detection of Peaton virus in a calf with hydranencephaly in Israel. Vet. Med. Sci. 2018, 5, 87-92. [CrossRef]

130. Hubalek, Z. Mosquito-borne viruses in Europe. Parasitol. Res. 2008, 103, 29-43. [CrossRef]

131. Harding, S.; Greig, J.; Mascarenhas, M.; Young, I.; Waddell, L.A. La Crosse virus: A scoping review of the global evidence. Epidemiol. Infect. 2018, 1-13. [CrossRef]

132. Anonymous. La Cross Encephalitis. Available online: https://www.cdc.gov/lac/index.html (accessed on 12 March 2019).

133. Kappus, K.D.; Calisher, C.H.; Baron, R.C.; Davenport, J.; Francy, D.B.; Williams, R.M. La Crosse virus infection and disease in western North Carolina. Am. J. Trop. Med. Hyg. 1982, 31, 556-560. [CrossRef]

134. Szumlas, D.E.; Apperson, C.S.; Powell, E.E.; Hartig, P.; Francy, D.B.; Karabotsos, N. Relative abundance and species composition of mosquito populations (Diptera: Culicidae) in a La Crosse virus-endemic area in western North Carolina. J. Med. Entomol. 1996, 33, 598-607. [CrossRef]

135. Miller, B.R.; DeFoliart, G.R.; Yuill, T.M. Vertical transmission of La Crosse virus (California encephalitis group): Transovarial and filial infection rates in Aedes triseriatus (Diptera: Culicidae). J. Med. Entomol. 1977, 14, 437-440. [CrossRef]

136. Gerhardt, R.R.; Gottfried, K.L.; Apperson, C.S.; Davis, B.S.; Erwin, P.C.; Smith, A.B.; Panella, N.A.; Powell, E.E.; Nasci, R.S. First isolation of La Crosse virus from naturally infected Aedes albopictus. Emerg. Infect. Dis. 2001, 7, 807-811. [CrossRef]

137. Lambert, A.J.; Blair, C.D.; D’Anton, M.; Ewing, W.; Harborth, M.; Seiferth, R.; Xiang, J.; Lanciotti, R.S. La Crosse virus in Aedes albopictus mosquitoes, Texas, USA, 2009. Emerg. Infect. Dis. 2010, 16, 856-858. [CrossRef]

138. Westby, K.M.; Fritzen, C.; Paulsen, D.; Poindexter, S.; Moncayo, A.C. La Crosse Encephalitis virus infection in field-collected Aedes albopictus, Aedes japonicus, and Aedes triseriatus in Tennessee. J. Am. Mosq. Control Assoc. 2015, 31, 233-241. [CrossRef]

139. Harris, M.C.; Dotseth, E.J.; Jackson, B.T.; Zink, S.D.; Marek, P.E.; Kramer, L.D.; Paulson, S.L.; Hawley, D.M. La Crosse virus in Aedes japonicus japonicus mosquitoes in the Appalachian region, United States. Emerg. Infect. Dis. 2015, 21, 646-649. [CrossRef]

140. Grimstad, P.R.; Kobayashi, J.F.; Zhang, M.B.; Craig, G.B., Jr. Recently introduced Aedes albopictus in the United States: potential vector of La Crosse virus (Bunyaviridae: California serogroup). J. Am. Mosq. Control Assoc. 1989, 5, 422-427. [PubMed]

141. Sardelis, M.R.; Turell, M.J.; Andre, R.G. Laboratory transmission of La Crosse virus by Ochlerotatus j. japonicus (Diptera: Culicidae). J. Med. Entomol. 2002, 39, 635-639. [CrossRef] [PubMed] 
142. Grimstad, P.R. Jamestown Canyon virus. In Encyclopedia of Arthropod-Transmitted Infections of Man and Domestic Animals; Service, M.W., Ashford, R.W., Eds.; CABI Publishing: New York, NY, USA, 2001; pp. 235-239.

143. Grimstad, P.R. California group virus disease. In The Arboviruses: Epidemiology and Ecology; Monath, T.P., Ed.; CRC Press: Boca Raton, FL, USA, 1988; pp. 99-136.

144. Whitman, L.; Wallis, R.C.; Leventhal, E.A. Isolation of a California-group arbovirus from Aedes abserratus (Felt and Young) in Simsbury, Connecticut. Am. J. Trop. Med. Hyg. 1968, 17, 449-450. [CrossRef] [PubMed]

145. Andreadis, T.G.; Anderson, J.F.; Armstrong, P.M.; Main, A.J. Isolations of Jamestown Canyon virus (Bunyaviridae: Orthobunyavirus) from field-collected mosquitoes (Diptera: Culicidae) in Connecticut, USA: A ten-year analysis, 1997-2006. Vector Borne Zoonotic Dis. 2008, 8, 175-188. [CrossRef]

146. Boromisa, R.D.; Grayson, M.A. Incrimination of Aedes provocans as a vector of Jamestown Canyon virus in an enzootic focus of northeastern New York. J. Am. Mosq. Control Assoc. 1990, 6, 504-509.

147. Heard, P.B.; Zhang, M.B.; Grimstad, P.R. Isolation of Jamestown Canyon virus (California serogroup) from Aedes mosquitoes in an enzootic focus in Michigan. J. Am. Mosq. Control Assoc. 1990, 6, 461-468. [PubMed]

148. Walker, E.D.; Grayson, M.A.; Edman, J.D. Isolation of Jamestown Canyon and snowshoe hare viruses (California serogroup) from Aedes mosquitoes in western Massachusetts. J. Am. Mosq. Control Assoc. 1993, 9 , 131-134. [PubMed]

149. Boromisa, R.D.; Grimstad, P.R. Virus-vector-host relationships of Aedes stimulans and Jamestown Canyon virus in a northern Indiana enzootic focus. Am. J. Trop. Med. Hyg. 1986, 35, 1285-1295. [CrossRef]

150. Anderson, J.F.; Main, A.J.; Armstrong, P.M.; Andreadis, T.G.; Ferrandino, F.J. Arboviruses in North Dakota, 2003-2006. Am. J. Trop. Med. Hyg. 2015, 92, 377-393. [CrossRef]

151. Bond, J.O.; Hammon, W.M.; Lewis, A.L.; Sather, G.E.; Taylor, D.J. California group arboviruses in Florida and report of a new strain, Keystone virus. Public Health Rep. 1966, 81, 607-613. [CrossRef]

152. LeDuc, J.W.; Burger, J.F.; Eldridge, B.F.; Russell, P.K. Ecology of Keystone virus, a transovarially maintained arbovirus. Ann. N. Y. Acad. Sci. 1975, 266, 144-151. [CrossRef]

153. Issel, C.J.; Hoff, G.L.; Trainer, D.O. Serologic evidence of infection of white-tailed deer in Texas with three California group arboviruses, (Jamestown Canyon, San Angelo, and Keystone). J. Wildl. Dis. 1973, 9, $245-248$. [CrossRef]

154. Watts, D.M.; LeDuc, J.W.; Bailey, C.L.; Dalrymple, J.M.; Gargan, T.P., 2nd. Serologic evidence of Jamestown Canyon and Keystone virus infection in vertebrates of the DelMarVa Peninsula. Am. J. Trop. Med. Hyg. 1982, 31, 1245-1251. [CrossRef]

155. Watts, D.M.; Bailey, C.L.; Roberts, N.T.; RF, T.A.; Dalrymple, J.M.; Clark, G.C. Maintenance and transmission of Keystone virus by Aedes atlanticus (Diptera: Culicidae) and the gray squirrel in the Pocomoke Cypress Swamp, Maryland. J. Med. Entomol. 1988, 25, 493-500. [CrossRef]

156. Sudia, W.D.; Newhouse, V.F.; Calisher, C.H.; Chamberlain, R.W. California group arbo-viruses: Isolations from mosquitoes in North America. Mosq. News 1971, 31, 576-600.

157. Parkin, W.E.; Hammon, W.M.; Sather, G.E. Review of current epidemiological literature on viruses of the California arbovirus group. Am. J. Trop. Med. Hyg. 1972, 21, 964-978. [CrossRef]

158. Lednicky, J.A.; White, S.K.; Stephenson, C.J.; Cherabuddi, K.; Loeb, J.C.; Moussatche, N.; Lednicky, A.; Morris, J.G., Jr. Keystone virus isolated from a Florida teenager with rash and subjective fever: Another endemic arbovirus in the Southeastern United States? Clin. Infect. Dis. 2019, 68, 143-145. [CrossRef]

159. Bardos, V.; Medek, M.; Kania, V.; Hubalek, Z. Isolation of Tahyna virus from the blood of sick children. Acta Virol. 1975, 19, 447.

160. Rodl, P.; Bardos, V.; Ryba, J. Experimental transmission of Tahyna virus (California group) to wild rabbits (Oryctolagus cuniculus) by mosquitoes. Folia Parasitol. (Praha) 1979, 26, 61-64.

161. Aspöck, H.; Kunz, C. Felduntersuchungen über die Bedeutung des Igels (Erinaceus europaeus roumanicus Barrett-Hamilton) im Zyklus des Tahyna-virus. Zentralbl Bakteriol. 1970, 213, 304-310.

162. Bardos, V.; Danielova, V. The Tahyna virus-A virus isolated from mosquitoes in Czechoslovakia. J. Hyg. Epidemiol. Microbiol. Immunol. 1959, 3, 264-276.

163. Danielová, V.; Hájková, Z.; Kolman, J.M.; Málková, D.; Minár, J.; Smetana, A. Results of virological examination of mosquitoes in Southern Moravia in 1962-1964. Cesk. Epidemiol. Mikrobiol. Imunol. 1966, 15, 178-184. [PubMed]

164. Kolman, J.M.; Malkova, D.; Nemec, A.; Smetana, A.; Hajkova, Z.; Minar, J. The isolation of the Tahyna virus from the mosquito Aedes vexans in Southern Moravia. J. Hyg. Epidemiol. Microbiol. Immunol. 1964, 8, 380-386. 
165. Hannoun, C.; Panther, R.; Corniou, B. Isolation of Tahyna virus in the South of France. Acta Virol. 1966, 10, 362-364

166. Balducci, M.; Verani, P.; Lopes, M.C.; Sacca, G.; Gregorig, B. Isolation of Tahyña virus from Aedes mosquitoes in Northern Italy (Gorizia Province). Acta Virol. 1968, 12, 457-459.

167. Traavik, T.; Mehl, R.; Wiger, R. California encephalitis group viruses isolated from mosquitoes collected in Southern and Arctic Norway. Acta Pathol. Microbiol. Scand. B 1978, 86B, 335-341. [CrossRef]

168. Arcan, P.; Topciu, V.; Rošiu, N.; Csaky, N. Isolation of Ťahyňa virus from Culex pipiens mosquitoes in Romania. Acta Virol. 1974, 18, 175.

169. Hubalek, Z.; Sebesta, O.; Pesko, J.; Betasova, L.; Blazejova, H.; Venclikova, K.; Rudolf, I. Isolation of Tahyna virus (California encephalitis group) from Anopheles hyrcanus (Diptera, Culicidae), a mosquito species new to, and expanding in, Central Europe. J. Med. Entomol. 2014, 51, 1264-1267. [CrossRef]

170. Anonymous. VMD authorises SBV vaccine for use in the UK. Vet. Rec. 2013, 172, 543.

171. Anonymous. Schmallenberg virus vaccine. Vet. Rec. 2015, 177, 321.

172. EMA. Zulvac SBV. 2015. Available online: https://www.ema.europa.eu/medicines/veterinary/EPAR/zulvacsbv (accessed on 25 March 2019).

173. Kim, Y.H.; Kweon, C.H.; Tark, D.S.; Lim, S.I.; Yang, D.K.; Hyun, B.H.; Song, J.Y.; Hur, W.; Park, S.C. Development of inactivated trivalent vaccine for the teratogenic Aino, Akabane and Chuzan viruses. Biologicals 2011, 39, 152-157. [CrossRef]

174. Patta, C.; Giovannini, A.; Rolesu, S.; Nannini, D.; Savini, G.; Calistri, P.; Santucci, U.; Caporale, V. Bluetongue vaccination in Europe: The Italian experience. Vet. Ital. 2004, 40, 601-610.

175. Zientara, S.; MacLachlan, N.J.; Calistri, P.; Sanchez-Vizcaino, J.M.; Savini, G. Bluetongue vaccination in Europe. Expert Rev. Vaccines 2010, 9, 989-991. [CrossRef] [PubMed]

176. Sakkas, H.; Bozidis, P.; Franks, A.; Papadopoulou, C. Oropouche fever: A review. Viruses 2018, $10,175$. [CrossRef] [PubMed]

177. Carpenter, S.; Mellor, P.S.; Torr, S.J. Control techniques for Culicoides biting midges and their application in the U.K. and northwestern Palaearctic. Med. Vet. Entomol. 2008, 22, 175-187. [CrossRef]

178. Wernike, K.; Conraths, F.; Zanella, G.; Granzow, H.; Gache, K.; Schirrmeier, H.; Valas, S.; Staubach, C.; Marianneau, P.; Kraatz, F.; et al. Schmallenberg virus-Two years of experiences. Prev. Vet. Med. 2014, 116, 423-434. [CrossRef]

179. Corbel, V.; Stankiewicz, M.; Pennetier, C.; Fournier, D.; Stojan, J.; Girard, E.; Dimitrov, M.; Molgo, J.; Hougard, J.M.; Lapied, B. Evidence for inhibition of cholinesterases in insect and mammalian nervous systems by the insect repellent DEET. BMC Biol. 2009, 7, 47. [CrossRef]

180. Mayer, S.V.; Tesh, R.B.; Vasilakis, N. The emergence of arthropod-borne viral diseases: A global prospective on dengue, chikungunya and zika fevers. Acta Trop. 2017, 166, 155-163. [CrossRef] [PubMed] 